\title{
The Need for Public-Private Partnership Model in the South African Coal-Mining Industry
}

\author{
Ken Mathu
}

\author{
Vaal University of Technology, South Africa
}

\section{Doi:10.5901/mjss.2014.v5n4p224}

\section{Abstract}

Coal is a strategic commodity in South Africa as it is the Primary source of energy in form of electricity and synthetic liquidfuels. It is also a feedstock in the heavy industries that include steel, cement, aluminium smelters and paper. Its role in socioeconomic development spans over 100 years. Therefore, the importance of coal supply chain cannot be overemphasised. The mining industry and the role players comprises the South African government, public and private enterprises. Hence, there is need for collaboration of the three parties in a public-private partnership (PPP) model to enhance operational effectiveness and efficiency. The government role in the legislative environment, issuing of exploration, mining and water licenses among others is crucial for the industry. The state-owned corporations such as Transnet, the only national rail transport logistics company and electricity supply company (Eskom), the main electricity generating company and the leading customer/consumer of the South African coal underpins the extent of the state involvement in the industry. The private sector role of ownership of the coal-mines is dominated by the big five international organisations namely BHP Billiton, Anglo Coal, Xstrata/Glencore, Sasol and Exxaro and the black economic empowerment (BEE) companies or junior miners. The electricity and the liquid-fuels types of energy impact on all sectors of the economy. It is this complex relationship by all the role players in the coal-mining industry supply chain that requires enhanced collaboration in a PPP model to harmonise the entire operations in the value-chain. The relationship of the industry players was observed through the mining process, coal transportation to the domestic customers/consumers and export markets. The coal transport logistics infrastructures comprising conveyor belts, rail, road and water were explored and constraints requiring PPP solutions identified.

Keywords: coal-mining, electricity, liquid fuels, private-public partnership, collaboration

\section{Introduction}

Coal has continued to play a significant role in the socio-economic development of South Africa since its discovery over 100 years ago. It has been and has continued to be instrumental in the industrial, agricultural and social development in the country.

The coal supply chain role players include the South African government; the state-owned corporations Transnet and Eskom, South African Energy Regulator (NERSA); the five leading mining companies namely BHP Billiton, Anglo America, Xstra/Glencore; Sasol and Exxaro and the black economic empowerment (BEE) companies or junior miners. The other crucial role players include the Chamber of Mines of South Africa and Richards Bay Coal Terminal (RBCT).

The socio-economic impacts of the industry are experienced through the complex supply chain whereby most customers are also the major consumers of the commodity. The bulk of coal produced in the country is consumed internally for the generation of electricity and the production of synthetic liquid-fuels and petrochemical products. The state owned corporation Eskom is the leading coal customer buying the commodity for its coal-fired power stations. The energy company Sasol has its own coal mines and consumes most of the coal mined for the production of synthetic liquid-fuels, petrochemical products and for export market. The other coal customers include heavy industries for steel, cement, aluminium smelters, paper and homes among others.

All the role players contribute significantly to the coal-mining supply chain. The South African government plays a crucial role in the legislative environment and licensing various processes in the industry. The state-owned corporation Transnet role is that of the national rail transport logistics and Eskom is the leading coal customer/consumer for the generation of electricity. The five leading coal-mining companies produce over $80 \%$ of the South African coal while the junior miners produce the other $20 \%$. NERSA is the national energy regulatory body; the Chamber of Mines acts as the liaison between the private mining companies, labour unions and the government. Also included is RBCT which is the leading coal export terminal in South Africa and the world.

The PPP business model would enhance the collaboration of the role players in the coal supply chain through operational effectiveness and efficiency by reducing the red tape between the public and private players. The model 
would facilitate, streamline and expedit policy interpretation for the mining industry. It would enhance coal transport logistics by introducing intermodal transport systems whereby, rail would be predominantly used in coal transportation as the road assumes supply role servicing market end of the value-chain. The process spinoff would be socio-economic and environmental in reduction of the road damage, accidents and air/noise-pollution.

\section{Problem Statement}

The problem statement for the study was to establish the benefits to be realised by the introduction of public-private partnership (PPP) model in the South African coal mining industry supply chain and how it would enhance collaboration and integration of the role players in the government, public enterprises and private sector.

\section{The Purpose of the Study}

The purpose of this study was to establish how public-private partnership model for the South African coal mining supply chain would enhance operational efficiency and effectiveness and increase output. The model would focus on activities such as:

1. Improved communication between the public and private role players

2. Speed up policy interpretation and implementation

3. Streamline coal transportation logistics

4. Enhance sustainability in the industry

\section{Methodology}

The study adopted a qualitative research paradigm. According to Cooper and Schindler (2008: 162-168) the outcome of the qualitative interview depends very much on how the researcher prepares the participants for the interview. 'Qualitative research has substance, gives insight, shows sensitivity and is unique in conceptualisation, yet grounded in data' (Corbin \& Strauss 2008: 302).

This study covers various aspects that include selection of participants, undertaking the interview, feedback on the interview for validity/reliability and facilitating data collection in a recorded form using an audio data recorder and field notes. Citing Goddard and Melville (2005: 49) the researcher must not direct the participant's answer through his tone of voice or rephrase the research question. Research design involves activities of 'collecting and analysing data, developing and modifying theory, elaborating or refocusing the research questions, identifying and addressing validity threat' (Maxwell 2005: 2).

A purposive sampling process was used for the selection and profile of participants. The process aimed to enhance understanding of the selected people and groups as they were selected for a specific purpose, task or expertise in research. 'The researcher should be in a position to expound the use of purposive sampling in order to instill confidence and validity for research findings' (Devers \& Frankel 2000: 264-265). The participants for this study were the top professionals who were also involved in decision making in their respective organisations in order to provide credibility to the study. There were 14 respondents earmarked for this research and 13 of them responded: 12 respondents were interviewed at their work place while 1 respondent provided a telephonic interview. The interview population of the 13 respondents comprised 4 Chief Executives and 9 senior professionals in the mining and affiliated industries nominated by their respective chief executives.

\subsection{Sample and procedures}

In order to obtain access to individuals and institution, the researcher is required to obtain permission from gate-keepers of the target institutions (Ehigie \& Ehigie 2005: 622-623). The permission to conduct research either oral or written is paramount (Cooper \& Schindler 2008: 37). The objectives for the research were addressed at the initiation stage as the researcher approached the institutions' gate-keepers by stipulating the value proposition for the study, purpose and ethical considerations that also addressed the 'informed consent' (admissibility for research process).

The researcher requires skills in negotiation and relationship building to be able to successfully access the prospective respondents. In this study, the researcher approached the selected participants via telephone and e-mail and briefed them on the value proposition for the project. Since the respondents were senior executives in their respective 
companies, some of them responded directly, while the others responded through their personal assistants. In two occasions the researcher was invited to give a presentation on the purpose of the research before the consent to interview was granted. A research introduction letter from the Vaal University of Technology formed part of the presentation. The content of the letter included the introduction of the researcher, confidentiality undertakings and the use of audio digital data recorder for recording the interviews.

\subsection{Data analysis}

The research data was collected from the respondents using the audio digital data recorder and from the field notes. The collected data was transcribed and content analysis was used for the translation and analysis. The emerging themes and sub-themes were recorded and evaluated to establish constraints that exist in the industry that would be resolved by the public-private partnership model.

\subsection{Reliability and validity (Measures of Trustworthiness)}

The reliability and validity of data from this study were ascertained through triangulation: comparing data from the interviews, feedback from the participants and from the literature. The researcher's field notes articulated the respondents' output. Some participants also provided written clarifications of some of their contributions after the interview. 'Multiple sources lead to a better understanding of the phenomena being studied' (Willis 2007: 219). Triangulation enhances validity and richness of data by looking at issues from different angles (Lee \& Lings 2008: 239).

\subsection{Ethical procedures}

According to Eriksson and Kovalainen (2008: 68) research is vulnerable to 'lies, fraud and wrong-doing' hence, ethical adherence is paramount. The ethical issues for this study were addressed through the research introduction letter from the Vaal University of Technology addressed to those participants who had accepted the invitation for the interview. The letter provided confidentiality, anonymity and use of pseudonyms between the respondent and the researcher.

\section{Results}

Table 1: Themes and sub-themes emanating from the interviews

\begin{tabular}{|c|c|}
\hline Themes & Sub-Themes \\
\hline $\begin{array}{l}\text { Coal: origin, quality, business model, } \\
\text { production, consumption and trade (economic } \\
\text { benefits/welfare of employees and } \\
\text { communities) }\end{array}$ & $\begin{array}{l}\text { - Coal and its properties, reserves, production, consumption and trade } \\
\text { - Employee satisfaction } \\
\text { - Community welfare } \\
\text { - Environmental impact }\end{array}$ \\
\hline $\begin{array}{l}\text { Legislative environment (MPRDA, NEMA, } \\
\text { NERSA) }\end{array}$ & $\begin{array}{l}\text { - } \text { MPRDA Act of } 2002 \\
\text { - NEMA Act of } 1998 \\
\text { - NERSA }\end{array}$ \\
\hline $\begin{array}{l}\text { Role players: coal mines (private), Transnet- } \\
\text { rail (public), Chamber of mines (private) }\end{array}$ & $\begin{array}{l}\text { - Coal-mines } \\
\text { - Transnet (rail transport) } \\
\text { - Chamber of mines (advisory roles) }\end{array}$ \\
\hline $\begin{array}{l}\text { Transport infrastructures: conveyor belts, rail, } \\
\text { road, water }\end{array}$ & $\begin{array}{l}\text { - Rail for export coal and less for domestic transport } \\
\text { - Road in power station areas } \\
\text { - } \text { Conveyor belts for collieries tied to power stations }\end{array}$ \\
\hline Ownership of the rail/TFR-TRANSNET & - State ownership of rail hinders maximum collaboration \\
\hline Skills shortage across the industry & $\begin{array}{l}\text { - Mining engineers, mangers, artisans, mining equipment, rolling stock, trains, old rail } \\
\text { gauge }\end{array}$ \\
\hline $\begin{array}{l}\text { Environmental issues: pursuing green } \\
\text { initiative, social responsibility. Commitment to } \\
\text { "cradle to grave" philosophy of green } \\
\text { environment }\end{array}$ & $\begin{array}{l}\text { - Environmental degradation: carbon emissions, dust, noise and diesel pollution } \\
\text { - Coal transport by road } \\
\text { - "cradle to cradle" and "cradle to grave", product reuse, recycle rehabilitation (soil, } \\
\text { water, mines) }\end{array}$ \\
\hline
\end{tabular}

Source: Mathu (2011: 222-223) 
Table 1 expresses the themes and sub-themes emanating from the study. They comprise constraints that exist with government, public and private enterprises in the South African coal mining industry. The seven major themes that emerged included coal as a commodity, legislative environment, industry role players, transport infrastructures, ownership of the rail (Transnet), skills shortage and the environmental issues. Several sub-themes also emerged and together with the main themes, they are discussed hereunder:

\section{Discussion}

There were seven major constraints experienced in the South African coal mining industry supply chain that emerged from the interviews conducted with the respondents. The constraints covered a wide range of issues including coal and its properties; legislative environment; industry role players (government, public and private enterprises); transport infrastructure, ownership of TFR-Transnet; skills shortage and environmental issues. The respondents were professionals and decision makers from across the industry as elaborated herewith:

\subsection{Coal and its properties}

Coal is a fossil fuel and a primary source of energy in South Africa. Coal is formed from accumulation of dead vegetation over many years, undergoing a slow decaying process turning into peat that transforms into coal seams (Anglo Coal 2007: 47). According to Abbott, Apostolic, Goodman, Hortsman, Jenner, Jewell, Labhart, Maragos, May, Sunderman, Parke, Stein, Wengler and Went (2009: 53) the slow formation process that takes millions of years make coal a nonrenewable source of energy.

South African coal is associated with the Karoo rock formations which extend over the present day Free State, Mpumalanga, Limpopo and Western Natal. The chemical composition and properties of coal determine its usage. South African coal is less reactive, harder and has lower sulphur content compared to coal from the Northern hemisphere. The bulk of South African coal is bituminous or thermal grade suitable as fuel for electricity generation and anthracite suitable for metallurgical plants (Lang 1995: 20).

Carbon contents determine the calorific value (heat value) and it is used in the classification of coal (Abbott et al., 2009: 53) viz:

1. Lignite coal: It is the lowest ranked coal with carbon content of $25-35 \%$ and it is mainly used in power stations to generate electricity.

2. Sub-bituminous coal: It has higher calorific value than lignite, contains $35-45 \%$ carbon and its main use is also as fodder for the power stations.

3. Bituminous coal: It has higher calorific value than sub-bituminous, contains $45-86 \%$ carbon and it is used for power generation and in the metallurgy industry as 'coke' for the production of iron and steel.

4. Anthracite coal: It is the highest ranked coal in quality and it is hard, glossy and black. It possesses the highest calorific value, contains $86-97 \%$ carbon and it is mainly used for residential and commercial space heating.

5. Graphite coal: It possesses the same quality with anthracite and it is mainly used in pencil making and as a lubricant when powdered.

\subsection{South African coal reserves}

South Africa has coal reserves of approximately 30408 million tons, the sixth largest coal reserves in the world. The coal reserves are found in Mpumalanga, Free State, Limpopo, Kwa-Zulu Natal and Limpopo coalfields (DMR 2009:44).

The South African coalfields are mainly concentrated in the Mpumalanga coalfields where most of the coal-fired power plants are situated. The 650 kilometres rail line that transports coal to the Richards Bay Coal Terminal for export also runs from this area. Mpumalanga Province presently produces in excess of 70 percent of the South African coal, but the reserves are currently running low (depleting). It is estimated that from around 2020, coal mines in the Mpumalanga area will start relocating to the Waterberg coalfields in Limpopo Province which has abundant, untapped coal reserves (Chamber of Mines 2009:27).

There were 73 collieries in South Africa (Prevost 2009: 27). Most of them are owned by the five leading mining companies that produce over 80 percent of coal in the country and the others are owned by smaller mining companies (Black Economic Empowerment) also called junior miners. The national distribution of the collieries are: Free State (2); 
Gauteng (1); Kwazulu-Natal (7), Limpopo (2) and Mpumalanga (61). The five leading mining companies involved in the exploitation of coal from these coalfields are Anglo Coal, BHP Billiton, Exxaro, Xstrata and Sasol (DME 2007:44).

\subsection{South African coal mining business model}

There are two business models for coal mining in South Africa namely domestic and export models. The domestic model has three stages which comprises the mining process, transportation to the domestic customers/consumers and the processes at the customers' facilities who are usually the consumers. The export coal model also has three stages which are mining process, transportation to the coal export terminal by rail and shipping to overseas customers by sea. The export terminal is at Richards Bay along the Indian ocean coast of Kwa-Zulu Natal.

The following figure shows the South African coal mining business model depicting both domestic and export markets.

Figure 1: The South African Coal Mining Business Model for domestic and export markets

\section{Source: Mathu 2011: 63}

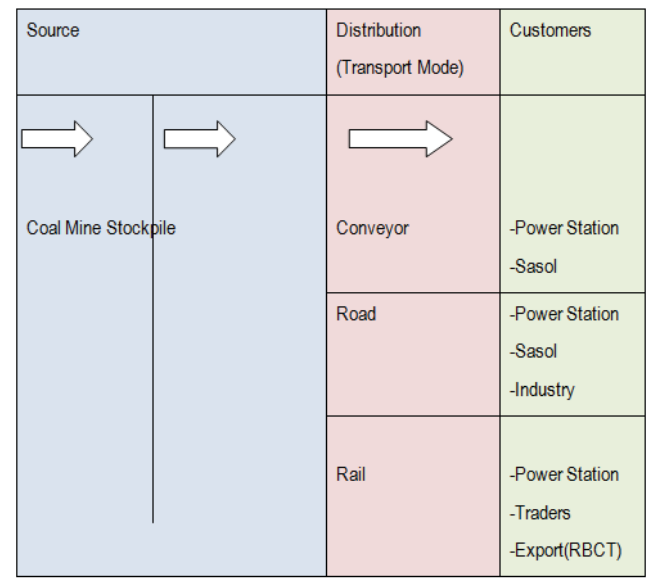

The South African coal mining business model has three main stages: source (coal mining/ beneficiation), transportation (mode of transport used) and customers/ consumers.

\subsubsection{Stage 1: Mining}

The mining process involves removal of overburden on the top of the mine and coal that is brought to the surface mixed with rocks. The rocks are sorted from coal and delivered to a dump site. Coal free of rocks is stockpiled on a site allocated near the mine.

\subsubsection{Stage 2: Distribution (Transportation)}

Three types of transport modes are used for local distribution to the customers conveyor, rail and road while rail and ship are used for export. The power station coal is delivered direct from the stockpiles and does not go through the beneficiation process. The bulk of the power station coal is delivered via conveyor belts. The rest is delivered by road and rail. The export coal is taken through the beneficiation process and delivered to the export terminal by rail. The coking coal for metallurgical industry, cement industry, aluminium smelters and for the traders is delivered by road and rail.

\subsubsection{Stage 3: Customers}

The domestic customers for coal are the power stations, SASOL, industry and traders while the export customers abroad are the power stations and industry. 


\section{Coal Production}

The South African coal mines are predominantly situated in the Mpumalanga coalfields. The future of South African coal mining is in Waterberg coalfields in the Limpopo Province after depletion of coal reserves in Mpumalanga deteriorates around 2020. Mining companies have already started identifying their relocation to Waterberg. The giant Medupi power station is located there and on completion it will be supplied by Exxaro mining company (Eskom 2011: 88)

A report from Eskom indicates that mining development has stalled in the last ten years. It also indicates a projection of up to 2018 comprising 43 new mines at an estimated cost of about R 100 billion and raising the 2008 national production estimate of $270 \mathrm{mtpa}$ to $370 \mathrm{mtpa}$ by 2018 . Those mines would be developed by the existing leading mining groups in the industry and just a few to be developed by the Black Economic Empowerment companies (Eskom 2009: 15).

South African coal production has stagnated since 2004 while consumption by Eskom has risen to meet the continued rising power demand. The scenario puts Eskom in competition with the other domestic consumers, resulting in price hikes and this has forced Eskom to use discarded coal from the big coal exporters in order to meet their requirements. The demand will continue to outstrip supply for some time until new coal mines come on stream (Smuts 2008:36). Presently, Eskom is building two giant coal-fired power stations Medupi and Kusile which will be completed in stages from 2014 (Eskom 2011: 88-89).

\section{Coal Consumption}

There are two categories of coal usage in South Africa namely domestic consumption and export markets. The domestic consumption is predominantly by Eskom power stations for the generation of electricity, Sasol for transformation into synthetic fuels and petrochemical products, steel and cement industries, aluminium smelters and homes for various applications.

\subsection{Coal for the generation of electricity (Eskom)}

Eskom is a South African government-owned power utility company that consumes the bulk of coal produced in the country as fuel for the generation of electricity through its current 13 coal-fired power plants which generate 88 per cent of the national electricity (Eskom 2009: 226). Eskom is one of the top 10 utilities in the world by generation capacity (Eskom 2009: iii). This is an indication of the size and capacity of the utility. The company's electricity generation mix comprises coal, hydro, pumped storage and some imports. This brings the total nominal capacity to 44193 megawatts (MW) (Eskom 2009: iii).

Eskom consumes approximately 50 percent of the coal produced in South Africa and approximately 66 percent of the total domestic coal consumption. Its consumption in 2011 was 124.7 million tons of coal (Eskom 2011: 11). The power crisis of 2007/2008 impacted heavily on the company and on the economy as well as communities. The coal stockpile at the power stations had deteriorated due to poor coal logistics, among other factors. As a result, Eskom was forced to step up coal transport by road to the detriment of the environment in the Mpumalanga area where most of the coal-fired stations are located (Bischoff 2009: 100).

This study established during the interviews that coal transportation is done 70 percent by conveyor belts, 24 percent by road and 6 percent by rail. The future plan is to reduce road transport to below 6 percent and increase rail transport to more than 24 percent. Eskom is under pressure to control costs and rail transport is viewed as being more economical, safer and sustainable (Eskom PE Division 2008: 12).

Eskom uses a network of national grid to transmit and distribute power directly or through municipalities. The national grid comprises 395 419km power lines (Eskom 2011: 169).

\subsection{Coal for production of liquid fuels and petrochemical products (Sasol)}

South African Synthetic Oils (Sasol) is a South African public company founded in 1950 and has international operations in a number of countries. The company manufactures a wide range of petrochemicals and synthetic fuels. It supplies a third of South Africa's liquid fuel requirements. It is also the country's single largest industrial investor, as well as the largest chemical feedstock producer. Its contribution to the Growth Domestic Product (GDP) is 4.7 percent amounting to R 40 billion a year (Sasol 2012: 11)). 
'Sasol's primary business is based on coal-to-liquid (CTL) and gas-to-liquid (GTL) technologies using FischerTropsch synthesis. CTL and GTL plants convert coal and natural gas respectively into liquid fuels. The company has GTL projects countries such as Qatar, Nigeria and china. The Fischer-Tropsch synthesis has adverse effect in massive emission of carbon dioxide into the atmosphere. Indeed, the company's Secunda plant is one of the world's single largest emitter of carbon dioxide.' (Sasol 2008: 83).

\subsection{Coal use in industry and homes}

Coal is transformed under high temperature of approximately 1000 degrees Celsius into coke for use as a reducing agent fuel in the smelters in blast furnaces (Crawford 1993: 5). It is used for cooking and space heating in homes and industries (Chamber of mines 2009: 25)

\section{Coal Trade}

The South African coal trade covers both domestic and export markets. The domestic market is dominated by Eskom, Sasol, steel and cement industries, aluminium smelters and domestic market comprises 75 percent of total coal produced in the country. The remaining 25 percent is exported. Taking example of 2008 , the distribution of the South African coal market estimated at 252.2 (Mt) was $194.3 \mathrm{Mt}$ for the domestic market and $57.9 \mathrm{Mt}$ for export. A further distribution ratios were as follows: power generation - Eskom (124.35mtpa), Sasol (44mtpa), industries (9mtpa), merchants (12.25mtpa) and exports (57.9mtpa) (Prevost 2008:7).

However, coal trade has stagnated in the last decade due to limited capacity of shipment from Mpumalanga coalfields by Transnet Freight Rail (TFR) for reasons such as inadequate wagons and other operational factors. According to Transnet 2013 Annual Report, TFR capacity reached 81mtpa and the projection is 97.5mtpa in 2020 (Transnet 2013: 140).

The local coal price per ton Free on Rail (FOR) averaged R 150.40 per ton in 2008, a 40.5 percent increase on the 2007 price. The average export price FOB (Free on Board) was R 704.62 per ton in 2008, a 94.5 increase over the 2007 price. The rise in local price was mainly attributed to higher mining costs resulting from higher input costs. Presently, the price of coal is USD 82.31 which is equivalent to ZAR823.10 at the exchange rate of R10 for 1USD (Coal Trader 2013: 1).

\section{Legislative Environment}

This study concentrated on the legislative environment from the South Africa's Department of Mineral Resources, Department of Water and Environmental Affairs and the National Energy Regulator of South Africa.

\subsection{Department of Mineral Resources (DMR)}

The Department of Mineral Resources (DMR), previously Department of Minerals and Energy (DME), uses the Mineral and Petroleum Resources Development Act (MPRDA) - Act 2002 (Act No. 28 of 2002) that was promulgated in April 2004 in the administration of the mining industry (Government Gazette 2006: 3).

\subsection{Department of Water and Environmental Affairs (DW\&EA)}

The Department of water and environmental affairs (DW \& EA) ensures that mines has environmental management plan (EMP) based on the principle of integrated environmental management as provided by the National Environmental Management Act (Act No. 107 of 1998) NEMA (Government Gazette 2010: 3).

\subsection{National Energy Regulator of South Africa (NERSA)}

The National Energy Regulator of South Africa (NERSA) is the precursor National Energy Regulator (NER) established in October 2005 to regulate the energy sectors in electricity, piped gas and petroleum. This study concentrates on the regulation of energy derived from coal which comprises electricity and synthetic liquid-fuels (NERSA 2009: 5).

Established under Section 3 of the National Energy Regulator Act, 2004 (Act No. 4 of 2004), NERSA's mandate is 
to maintain a delicate balance between the regulated energy industries, users and consumers (NERSA 2008:16). The regulatory body advises the electricity and other energy institutions on the tariffs they charge the consumers and arbitrates grievances between the consumers and the energy distributors, among other roles. This ensures that the end users and consumers receive appropriate service and pay the correct rates recommended by the government (NERSA 2009:11-15).

\subsection{Transport}

The modes of transport in the South African coal industry supply chain are conveyor belts, rail, road and marine or water transport.

\subsubsection{Conveyor belts}

In the South African coal mining industry, conveyors are used to transport coal to a number of power stations in the Mpumalanga area as a number of them are built next to the coal mines. The coal-fired power plants are designed with a coal mine next to them for the ease of supplying coal in a system called a 'tied-colliery' contract These are long-term contracts meant to ensure coal supply security to the power stations. Even the two new coal power stations currently under construction are designed on this model with 40 years long-term coal supply contracts (ESKOM 2009: 65).

However, this study has established a few instances where this model is not applicable, for example in the case of Majuba power station whereby the coal mine designated to supply the station could not be used due to geological problems. So the power station's coal requirement is delivered from other mines by road and rail. Presently, some of the coal mines in the Mpumalanga coalfields are affected by coal depletion and are not able to produce enough coal to meet the power stations' capacity so road and rail transportation are used to deliver the extra coal from outside coal mines. For instance, the mine that supplies Tutuka power station produces only $50 \%$ of the power plant's coal capacity so the rest has to be delivered from other mines by road and rail (ESKOM 2009:226).

\subsubsection{Rail Transport (Transnet/TFR)}

The South African rail network is operated by the state corporation TRANSNET through one of its business units Transnet Freight Rail (TFR). 'The TFR uses the national rail network comprising 22000 kilometres for freight transportation of which 1500 kilometres comprises heavy haul lines for export coal and iron ore. The rail network connects the ports to the hinterland of South Africa and the Sub-Sahara region. Services are primarily provided to customers in the mining, manufacturing, agriculture, forestry, automotive and intermodal sectors of the economy across the border trade and six African countries' (TRANSNET 2009:124).

South African rail freight is determined by the structural change in the economy from "a mining to a manufacturing focus". 'The main cost drivers in the rail freight industry include the long distances of transporting goods (minerals) from the mines to the ports and the massive labour costs as a percentage of the total operating costs. However, TRANSNET has an organised and efficient way of moving coal, iron ore and other resources, but the process of moving manufactured goods is still inefficient and unreliable. Mining haulage involves transportation of coal, iron ore, manganese, chrome, timber and other mineral resources. Moving of manufactured goods involves transportation of cement, fuel, chemicals and fast-moving consumer goods (FMCGs)' (DoT 2006: 50).

'The South African Department of Transport (DoT) Strategic Plan for 2010 to 2013 aims to make freight among other types of transport efficient and sustainable to the economy. This would enhance the Accelerated and Shared Growth Initiative for South Africa (AsgiSA) through collaboration of infrastructure development in transport, energy, mining, telecommunication, information technology, agriculture and Public Works'. The rail freight focuses on two corridors for mineral transportation namely coal from Mpumalanga Province to Richards Bay, a distance of $650 \mathrm{~km}$ and iron ore from Sishen in the Northern Cape to Saldanha Bay, a distance of 850km (DoT 2010: 2). include:

According to (TRANSNET 2009:124) the rail freight company focuses on some critical operational issues that

- sustained safety improvements;

- executing customer demands;

- locomotive and wagon efficiency improvements;

- review of operational processes to lower costs and the creation of better efficiencies; and 
- re-deployment of people-capacity to enhance operational performance, training and better skills to ensure a steady a steady movement towards best practices.

\subsubsection{Road}

The total land transportation in South Africa comprising the road and the rail usage, accounts for approximately 90 percent of the total transport with road comprising 66 percent of the market share. According to Lane (2010:33), road transport has advantages over the rail in that there is accessibility (road network available in most places), competition (resulting in improved service, reliability, operations, equipment and competitive pricing) and perceived use for crosssubsidisation,

Road freight has a competitive advantage over rail freight as the South African roads are maintained by the government, whereas the state owned corporation TRASNET is responsible for maintaining both the fleet and the rail tracks. South Africa has a national road network of 754600 kilometres. Table 4-1 shows the national distribution of the road types (DoT 2006: 80).

\subsubsection{Marine}

The marine transport in the South African coal mining industry supply chain is only used for export coal and the main export terminal is RBCT.

\subsubsection{Coal Export Terminal (RBCT)}

The port of Richards Bay is situated 170 kilometres north of Durban on the Indian ocean coastline. It was opened in 1976 and commenced with an export capacity of 10Mtpa. This capacity grew over the years and reached a capacity of 72Mtpa in 2008 (Goussard 2009:8). The capacity reached 76mtpa in 2009 (Prevost 2009: 7) and by 2010 its expansion reached 91mtpa. Richards Bay Coal Terminal (RBCT) is the largest single coal export terminal in the world, exporting more than 69 million tons annually (DMR 2009:47). In 2011 the port exported 65.5mt and 68.3mt in 2012 (Mining Weekly 2012: 1).

\subsection{Chamber of Mines of South Africa}

The Chamber of Mines of South Africa is a voluntary membership private organisation which was founded in 1889 to look into the affairs of the mining industry. The Chamber liaises with universities and international organisations for mining related research and bridges between the government, labour unions and the mining industry (Chamber of Mines 2009: i).

\subsection{Skills shortage}

The need for more coal-fired power stations and new coal mines calls for more skills in technical areas in the supply chain that includes engineering, transportation and equipment operations. According to Wilhelm (2009: 6) estimates, building 40 power stations would require 600 engineers and 2500 artisans.

\subsection{Environmental constraints}

All the participants reaffirmed a continuous liability in managing 'green' issues as required by the mining legislation and the willingness of their respective organisations to respond to the requirements. The legislation would ensure control of the dilapidated ownerless coal mines, continuous burning of coal mine dumps, air and water pollution.

The power generation from coal consumes approximately $50 \%$ of the total coal mined in South Africa and the production of synthetic liquid-fuels and petrochemicals consumes 18\%. These energy producing processes are the leading carbon emitters in the country and hope to employ more effective measures in future to control the emissions (Lloyd 2002: 47).

The environmental degradation by excessive use of transportation of coal by road would be controlled by building additional rail lines linking the coal mines with the power stations in future. The extensive use of rail transport would also reduce noise and air pollution. 
Hence, the philosophy of 'cradle to cradle' and 'cradle to grave' is becoming prevalent in the coal supply chain.

\section{The Future of Coal Mining in South Africa}

The future of South African coal mining lies in coalfields which were identified in the past, but were never exploited due to constraints such as the lack of infrastructure, difficult coal mining conditions, high ash content and low calorific value (CV). 'These massive areas include Waterberg, Springbok Flats, Limpopo, Soutpansberg, Tuli, Mabopane, Venda-Pafuri and the Free State coalfields. They contain younger coal compared to that of Mpumalanga coalfields. The Waterberg coalfields alone contain about 3.4 billion tons of coal or 11 percent of South African recoverable coal.' (Prevost 2008: 6-9)

The South African coal mining sector has medium and long-term plans to increase coal production capacity. 'Presently, the industry has R15.5 billion worth of projects underway which could yield about $36 \mathrm{Mt}$ of extra coal production, while also sustaining production at some mines. Another $63 \mathrm{Mt}$ worth approximately R 30 billion is in the final feasibility stage. It is estimated that about R100 billion will be invested in the industry over the next decade if targets are to be achieved.' (Chamber of Mines 2009:27).

With the Mpumalanga coalfields being presently overexploited, the future of South African coal production lies in the Waterberg coal fields in the Limpopo Province (Prevost 2010:17). Eskom plans to construct new power stations in the area in future, commencing with the R110 billion Medupi dry-cooled coal power station which is under construction outside Lephalale. The feedstock for the giant power plant of about 14.6 million tons of coal per year will be supplied by the Grootegeluk coal mine owned by Exxaro Resources. Another dry-cooled new coal power station with the same capacity Kusile is also under construction near the area and it will be supplied coal by Anglo Coal on completion (Eskom 2011: 89-90).

The availability of water is a significant factor in the coal-mining industry. Large volume of water is required for mining, beneficiation and processing purposes (Prevost 2008:11). 'In the case of the Waterberg coalfield, the availability of water is a major inhibiting factor. 'The Matimba power station uses water from Makola Dam outside Lephalale. Presently, more water could become available by raising the level of Makola Dam, but it would not be enough for the earmarked development in the area. A geo-hydrology study is also being carried out to establish the availability of water in the area.' (Van Vuuren 2009:15).

\section{Limitation of the Study}

The study being qualitative had a limitation on the number of participants. A total of 13 professionals from the coal mining industry and the role players were interviewed. Recruiting such high caliber professionals was time-consuming in accessing them and their institutions as explained in the methodology chapter. However, the response by the respondents from the industry was positive (13 approvals out of 14 proposals).

Accessing the industry had other limitations due to its nature as energy industry and energy is a sensitive subject because of its critical role in sustainable development. The institutions in the industry are not easily accessible without convincing reasons and introducing a research topic is not one of the most desired reasons to gain access. However, with skills and patience, it was possible to gain access and to successfully accomplish the project.

\section{Recommendations}

This study recommends implementation of a public-private partnership (PPP) model for the South African coal mining supply chain in order to streamline its operational efficiency and effectiveness. The model would focus on general operational issues and policy implementation.

\subsection{General recommendations:}

- The coal mining industry needs to move from internal focus to cross-enterprise collaborations. Such collaborations would enable industry players to look beyond the profit focus and start seeing the value of cooperation and information sharing with the other members of the value chain.

- An Integrated strategy on the development of the coal mining industry (ISDCM) need to be developed to facilitate communication among the role players in the coal mining industry.

- The industry should have long-term plans for skills development to address the skills deficiencies in the 
industry at all times.

- There should be a shift from road to rail for coal transportation to limit the environmental degradation by trucks.

\subsection{Policy recommendations:}

At a policy level the study recommends that the coal mining industry develops an Integrated Strategy on the Development of Coal Mining (ISDCM) for South Africa. The critical elements of the strategy should be:

- a policy legislative environment;

- working towards a common and shared vision in the industry;

- developing rail and infrastructure;

- developing skills;

- attracting new investors in the industry;

- diversifying ownership of the rail and Transnet; and

- managing the environment.

\section{References}

Abbott, K., Apostolik, R., Goodman, G., Jenner, M., Labhart, G., Maragos, S., May, M., Sunderman, A. D., Parke, J., Stein, J., Wengler, J. \& Went, P. 2009. Foundation of Energy Risk Management: An overview of the energy sector and its physical and financial markets. Global Association of Risk Professional (GARP). Hobken, NJ: John Wiley.

Anglo Coal. 2007. Annual Report.

Bischoff, F. 2009. Coal haulage. IMIESA, October, pp.100-101.

Chamber Of Mines Of South Africa. 2009. Annual Report.

Coal Trader. 2013. [Online Magazine]. Accessed: 22 December 2013.

Cooper, D. R. \& Schindler, P. S. 2008. 10th ed. Business Research Methods. New York: McGraw-Hill.

Corbin, J. \& Strauss, A. 2008. 3rd ed. Basics of Qualitative Research. Thousand Oaks (CA): Sage.

Crawford, O. 1993. Surface molecular anchoring in microfined liquid crystals near the nematic-smectic-A transition. [Online]. Available at: http:/link.aps.org/doi/10.1103/PhysRevE.48.1998. Accessed. 23 April 2009.

Denvers, K.J. \& Frankel, M. 2000. The study design in qualitative research-2: Sampling and Data Collection Strategies. Education for Health, Vol. 13, No. 2, pp. 263-271.

Ehigie, B. O. Ehigie, R. I. 2005. Applying qualitative methods in organisations: A note for industrial/organizational psychologists. The Qualitative Report Volume 10 Number 3 September, pp. 621-638. [Online.] Available at: http://www.nova.edu/ssss/QR/QR103/ehigie.pdf. Accessed: 13 September 2010.

Eskom, Primary Energy Division. 2008. Annual Report.

Eskom. 2009. Annual Report.

Eskom. 2011. Annual Report.

Exxaro. 2007. Annual Report.

Goddard, W. \& Melville, S. 2005. $2^{\text {nd }}$ ed. Research Methodology (An Introduction). Durban: Juta.

Goussard, L. 2009. New berth 306 expands capacity of RBCT. Civil Engineering, May, p.8.

Lane, T. 2010. Sustainable approach to freight in South Africa. Supply Chain Today, June, pp.32-33.

Kovalainen, A. 2008. Qualitative Methods in Business Research. London: Sage.

Lang, J. 1995. Coal Mining in the Life of South Africa. Cape Town: Jonathan Ball.

Lee, N. \& Lings, I. 2008. Doing Business Research: A Guide to Theory and Practice. London: Sage.

Lloyd, P. J. 2002. Coal Mining and Environment. Energy Research Institute, University of Cape Town.

Mathu, K. M. 2011. Supply Chain Constraints in South African Coal Mining Industry. Berlin: Lap Lambert.

Mining Weekly. 2012. [Online]. Available at: www.miningweekly.com Accessed: 10 January 2012.

Maxwell, J. A. 2005. 2nd.ed. Qualitative Research Design: A alternative Approach. Thousand Oaks (CA): Sage.

National Energy Regulator Of South Africa (NERSA). 2008. Annual Report.

National Energy Regulator Of South Africa (NERSA). 2009. Annual Report.

Prevost, X. 2008. Coal mining in South Africa. Inside Mining, pp. 6-9.

Prevost, X. 2009. Undergroung gasification. Inside Mining, September, pp. 7-9

Prevost, X. 2010. A clean future for coal. Inside Mining, April/May, pp. 14-17.

Republic Of South Africa (RSA). Department of Environmental Affairs and Tourism 2006. Environmental Management Plan (EMP). Government Gazette No. 28753. Vol. 490. Pretoria: Government Printer.

Republic Of South Africa (RSA). Department of Minerals and Energy. 2007/2008. South Africa's Mineral Industry (SAMI). Pretoria: Government Printers. 
Republic Of South Africa (RSA). Department of Mineral Resources. 2009. Molato (Bana le Basadi ba tlile go tlo rera Molato). Johannesburg: Primedia.

Republic Of South Africa (RSA). Department of Mineral Resources. 2010. Mining Licenses Moratorium No. 33511, Vol. 542, Pretoria, 31 August.

Republic Of South Africa (RSA). Department of Transport. 2006. Interventions to reduce freight and passenger transport costs. Pretoria: Government Printer.

Sasol. 2008. Sustainable Development Result.

Sasol 2012 Annual Report

Smuts, W. 2008. Why coal is King. Inside Mining, September, pp33-37.

Transnet. 2008. Annual Report.

Transnet. 2009. Annual Report.

Transnet. 2013. Annual Report

Van Vuuren, L. 2009. Coal Mining's Impact on Waterberg Under Microscope. The Waterwheel Journal, March/April, p. 14.

Wilhelm, A. 2009. Coal is King. Inside Mining, pp.6-9

Willis, J. W. 2007. Foundations of Qualitative Research (Interpretive and Critical Approach). London: Sage. 